\title{
Changes of secondary metabolites in Pinus sylvestris L. needles under increasing soil water deficit
}

\author{
Domingo Sancho-Knapik ${ }^{1,2}$ • María Ángeles Sanz ${ }^{3}$. José Javier Peguero-Pina ${ }^{1,2}$. \\ Ülo Niinemets ${ }^{4}$ Eustaquio Gil-Pelegrín ${ }^{1,2}$
}

Received: 13 September 2016/Accepted: 31 January 2017 /Published online: 8 March 2017

(C) INRA and Springer-Verlag France 2017

\begin{abstract}
- Key message A multiphasic response to water deficit was found in Scots pine primary and secondary metabolism. First, an increase of terpenoids coincided with the stomatal closure. Second, an accumulation of proline, ABA, and shikimic acid was detected when photosynthesis was negligible.

- Context Drought-induced mortality is characterized by a major needle yellowing followed by severe defoliation and whole branch death. Before these external visual symptoms of drought stress take place, different alterations occur in plant metabolism.
\end{abstract}

Handling Editor: Andrew Merchant

Contribution of the co-authors DSK, MAS, JJPP, ÜN, and EGP conceived the study and participated in its design. MAS led the compound extraction analysis while DSK, JJPP, and EGP led the physiological measurements. DSK and EGP ran the data analysis. DSK drafted the manuscript, and MAS, JJPP, ÜN, and EGP critically revised the manuscript.

Eustaquio Gil-Pelegrín

egilp@aragon.es

Domingo Sancho-Knapik

dsancho@cita-aragon.es

María Ángeles Sanz

masanzg@aragon.es

José Javier Peguero-Pina

jjpeguero@aragon.es

Ülo Niinemets

ylo.niinemets@emu.ee
- Aims This study aims to detect changes in primary and secondary metabolism of Pinus sylvestris L. in response to a decrease in soil water availability.

- Methods We analyzed needle water potential, photosynthetic characteristics, and concentrations of proline, terpenoids, shikimic acid, total polyphenols, and abscisic acid (ABA) in P. sylvestris through a 55-day soil water deficit period.

- Results Concentrations of most metabolites varied with the decrease in soil water availability, but changes in different compounds were triggered at different times, highlighting a multiphasic response. Increases in monoterpene and sesquiterpenoid content at moderate water deficit coincided with stomatal closure which preceded the accumulation of proline, ABA, and shikimic acid under severe water deficit when net photosynthesis was negligible.

- Conclusion This work confirms that most of the secondary metabolites under investigation in Pinus sylvestris did not increase until a moderate to severe water deficit was experienced, when photosynthesis was limited by stomatal closure.

1 Unidad de Recursos Forestales, Gobierno de Aragón, Centro de Investigación y Tecnología Agroalimentaria, 50059 Zaragoza, Spain

2 Instituto Agroalimentario de Aragón (IA2), CITA, Universidad de Zaragoza, Zaragoza, Spain

3 Área de Laboratorios de Análisis y Asistencia Tecnológica, Gobierno de Aragón, Centro de Investigación y Tecnología Agroalimentaria, 50059 Zaragoza, Spain

4 Institute of Agricultural and Environmental Sciences, Estonian University of Life Sciences, Kreutzwaldi1, 51014 Tartu, Estonia 
Keywords Abscisic acid · Gas exchange - Shikimic acid . Water deficit $\cdot$ Proline $\cdot$ Terpenoids $\cdot$ Water potential

\section{Introduction}

Tree populations are facing new and rapidly changing selective pressures such as more frequent and more severe droughts, threatening the conservation of forests and related ecosystem services (Lindner et al. 2010; Martínez-Vilalta et al. 2012). Northern hemisphere conifer Pinus sylvestris L. has an exceptionally wide range of dispersal from subarctic to close to Mediterranean and warm temperate ecosystems, extending to its southern distribution limit to different mountain ranges of the Iberian Peninsula (Matías and Jump 2012). In these southernmost habitats, this species appears sensitive to an increase in the aridity, as indicated by major tree deaths during severe drought episodes (Galiano et al. 2010; Peguero-Pina et al. 2011; Sanz et al. 2014). The onset of droughtdependent mortality is visible by general needle yellowing followed by severe defoliation and whole branch death in a large fraction of trees (Sanz et al. 2014).

Before these external visual symptoms of water deficit take place, numerous alterations in plant metabolism occur, including photosynthesis limitation, alteration of carbon allocation (Teskey et al. 1987), changes in nutrient uptake, and variations in the levels of soluble sugars, inorganic ions, and amino acids (Schulze 1991; Turtola et al. 2003). Most recent studies on water deficit effects have focused on photosynthetic metabolism (e.g., Niinemets and Keenan 2014); however, water deficit also leads to modifications in secondary metabolism, and these changes often have remained hidden, but might provide a better insight into species and genotype variations in drought responses and into fine-tuning of plant functioning at a given level of primary metabolism (Niinemets 2016).

As key changes under water deficit, several authors have reported accumulation of proline, which has been considered as a mechanism of osmotic adjustment helping plants to extract water from drier soils (Xiao et al. 2008; Verbruggen and Hermans 2008; Vilagrosa et al. 2010). However, changes in secondary metabolism should not be directly related to adjustments to water deficit, but to other co-occurring stresses that can threaten the weakened plants, including adjustment to potentially more severe herbivory and pathogen infections. In conifers, it has been demonstrated that water deficit can modulate the composition of the oleoresin, changing the terpenoid profiles (monoterpenes, sesquiterpenoids, and diterpenoids, in particular, resin acids) (Lluisà and Peñuelas 1998; Turtola et al. 2003). Moderate water deficit typically results in increased woody and needle terpene concentrations (Lluisà and Peñuelas 1998; Turtola et al. 2003), but severe water deficit can reduce terpene contents (Yani etal. 1993). The role of terpenoids in the resistance or susceptibility of trees to attacks by diseases, insects, and animals and the influence of water deficit on such attacks have been studied (Lluisà and Peñuelas 1998; Pureswaran et al. 2004; Moreira et al. 2009; Karanikas et al. 2010), but the effects of water deficit severity on terpenoid content and composition and the corresponding effects on plant-insect and plant-pathogen interactions are poorly understood. Apart from terpenoids, phenolics and lignin are also involved in plant defense (Gamir et al. 2014). These compounds derived from shikimic acid (Schafellner et al. 1999; Gamir et al. 2014), the contents of which also seem to increase under water deficit (Becerra-Moreno et al. 2015). In addition, the accumulation of other compounds such as abscisic acid (ABA) has also been related to water deficit (Munné-Bosch et al. 2009; Corcuera et al. 2012). Increase of ABA in water-deficient plants induces stomatal closure and reduces leaf growth (Tardieu et al. 1992; Brodribb and McAdam 2013), allowing to fine-tune the stomatal responses to water deficit.

Although changes in all of the abovementioned compounds have been related to water deficit, in most of the studies, only two situations have been considered - well-watered and plants subjected to water deficit-and they fail to investigate the metabolic transition through the development of the stress treatment. Moreover, the apparent contradictory results found in different papers about the effect of water deficit on the profile of some secondary compounds may be explained by the lack of a comparable experimental framework. In such a case, the interaction between water conservation and net $\mathrm{CO}_{2}$ uptake as water deficit increases recommends the simultaneous measurement of physiological parameters and secondary metabolites in order to establish a correspondence between them. For these reasons, the main objective of this study was to monitor changes in content of all the key metabolites through mild to severe soil water deficit together with primary plant physiological characteristics - water potential, stomatal conductance, and net $\mathrm{CO}_{2}$ uptake. More specifically, we have analyzed the contents of proline, terpenoids (monoterpenes, sesquiterpenoids, and resin acids), shikimic acid, total polyphenols, and $\mathrm{ABA}$ during a soil water deficit period in P. sylvestris, a species particularly threatened by global change. We hypothesized that the plant response as soil water deficit increases may reflect a timetable of coordinated events between primary and secondary metabolism, which could reveal the physiological thresholds behind major changes in secondary metabolism. Understanding such coordinated changes will provide a framework to diagnosing the deficit situation in plants before external visual symptoms of drought stress become perceptible.

\section{Materials and methods}

\subsection{Plant material and experimental conditions}

Scots pine (P. sylvestris L.) seeds from "Sistema Ibérico Septentrional" provenance $\left(41^{\circ} 54^{\prime} \mathrm{N}, 02^{\circ} 53^{\prime} \mathrm{W}\right.$; Soria, Spain) 
were sown and cultivated in 2000 (mixture of $80 \%$ substratum and $20 \%$ perlite in $500-\mathrm{mL}$ containers) inside a greenhouse. After the first growth cycle, seedlings were transplanted to 10 L containers, and after 2 years, they were again transplanted to 50 -L containers ( $80 \%$ substratum, $20 \%$ perlite) and cultivated in a common garden $\left(41^{\circ} 39^{\prime} \mathrm{N}, 0^{\circ} 52^{\prime} \mathrm{W}\right.$, Zaragoza, Spain; mean annual temperature $15.4{ }^{\circ} \mathrm{C}$, total annual precipitation $298 \mathrm{~mm}$ ). All plants were grown under the same environmental conditions and irrigated every 3 days.

On August 2012, eight trees (12 years old) were moved from outside into a greenhouse (mean daily temperature $18.1 \pm 0.5{ }^{\circ} \mathrm{C}$, mean daily relative humidity $77.6 \pm 1.1 \%$ ). Once there, trees were watered every second day to field capacity until September 12, 2012. At this date, watering of five experimental trees was stopped, while the other three trees were kept well-watered during the experiment as control trees. Soil water deficit was imposed for 55 days, and during the treatment, measurements of water potential and gas exchange were conducted periodically as the severity of water deficit increased. Measurements of water potentials were conducted at predawn while measurements of needle gas exchange were made at 8:00 h solar time (early morning). In addition, currentyear needle samples for metabolite measurements in experimental and control trees were collected at predawn and stored at $-80{ }^{\circ} \mathrm{C}$ for sample preservation until analysis.

\subsection{Water potential and gas exchange measurements}

Predawn water potential ( $\Psi_{\mathrm{pd}}, \mathrm{MPa}$ ) was measured in shoots of $P$. sylvestris with a Scholander pressure chamber following the methodological procedure described by Turner (1988). Net $\mathrm{CO}_{2}$ uptake $\left(A, \mu \mathrm{mol} \mathrm{CO}_{2} \mathrm{~m}^{-2} \mathrm{~s}^{-1}\right)$ and stomatal conductance $\left(g_{\mathrm{s}}, \mathrm{mmol} \mathrm{H}_{2} \mathrm{O} \mathrm{m}^{-2} \mathrm{~s}^{-1}\right)$ were measured in needles with a portable gas exchange system (CIRAS-2, PP Systems, Herts, UK). Measurements were performed at controlled cuvette $\mathrm{CO}_{2}$ concentration $\left(\mathrm{C}_{\mathrm{a}}\right)$ of $400 \mu \mathrm{mol} \mathrm{mol}{ }^{-1}$, photosynthetic quantum flux density incident on the leaf surface of $1300 \mu \mathrm{mol}$ photons $\mathrm{m}^{-2} \mathrm{~s}^{-1}$, and ambient relative humidity.

\subsection{Analysis of monoterpenes and sesquiterpenoids and resin acid contents}

For monoterpene and sesquiterpenoid analysis, frozen needles were cut into small pieces, introduced in vial tubes, and extracted twice with $n$-hexane at room temperature for $2 \mathrm{~h}$. The extracts were filtered (PTFE $0.20 \mu \mathrm{m}$ ), and $1 \mu \mathrm{L}$ was injected in a gas chromatography-mass spectrometer (GC-MS) (Agilent Technologies GC 6890 Series, MSD 5973N). 1Chlorooctane was added as an internal standard.

Resin acids were extracted from freeze-dried and powdered needles, basically following the methodology of Gref and Ericsson (1985). One hundred milligrams was extracted with diethyl ether/petroleum ether $(1: 1, v / v)$ and twice with diethyl ether. Supernatants were combined and evaporated to dryness under a stream of nitrogen. The residue was redissolved in $1 \mathrm{~mL}$ of diethyl ether and filtered $(0.22 \mu \mathrm{m}$ Nylon filter $)$. Heptadecanoic acid was used as an internal standard. An aliquot of extract was dried again before derivatization that was performed with $\mathrm{N}, \mathrm{O}$-bis-(trimethylsilyl)-trifluoroacetamide with trimethylchlorosilane (BSTFA-TMS)/acetonitrile (1:1; $v / v)\left(90 \mathrm{~min}, 75^{\circ} \mathrm{C}\right)$. One microliter of the solution was injected in the GC-MS.

Separation of the compounds was carried out with a HP$5 \mathrm{MS}$ column $(30 \mathrm{~m}, 0.25 \mathrm{~mm}, 0.25 \mu \mathrm{m})$. The temperature program for monoterpenes and sesquiterpenoids was $60^{\circ} \mathrm{C}$ isothermal $1 \mathrm{~min}$, increased to $246^{\circ} \mathrm{C}$ at $3{ }^{\circ} \mathrm{C} \mathrm{min}{ }^{-1}$. For resin acids, the temperature program was $60^{\circ} \mathrm{C}$ isothermal $2 \mathrm{~min}$, increased to $270^{\circ} \mathrm{C}$ at $5^{\circ} \mathrm{C} \mathrm{min}^{-1}$. Helium was used as a carrier gas. Injector temperature was $220^{\circ} \mathrm{C}$ in split mode (ratio $1: 10$ ). The transfer line temperature was $240^{\circ} \mathrm{C}$. The mass selective detector was operated in electron impact mode at $70 \mathrm{eV}$. MS source and MS quad temperatures were 230 and $150{ }^{\circ} \mathrm{C}$, respectively, for monoterpenes and sesquiterpenoids and 250 and $200{ }^{\circ} \mathrm{C}$, respectively, for resin acids. An MSD ChemStation (ver. E.02.00) workstation was used for data capture and processing with Scan and the selected ion monitoring (SIM) techniques. The identification of the chemical constituents was based on comparisons of their relative retention times and mass spectra with those obtained from authentic standards and/or mass spectra in NIST MS search 2.0 and Wiley 275 libraries. Further, the Kovats index (KI) was calculated using a homologous series on $n$-alkanes (Adams 2009).

\subsection{Abscisic acid determination}

Fifty milligrams of lyophilized tissue was extracted twice with $3 \mathrm{~mL}$ of acetone/water/formic acid (80:19:1, v/v/v) (30 min, $2000 \mathrm{rpm}$ ) and centrifuged (15 min, $\left.3000 \mathrm{rpm}, 4{ }^{\circ} \mathrm{C}\right)$. The acetone was evaporated under a nitrogen stream, and the remaining aqueous extract was adjusted to $1.2 \mathrm{~mL}$ with Milli-Q water. The extract was partitioned twice with diethyl ether, dried under nitrogen, and redissolved in $500 \mu \mathrm{L}$ acetonitrile/ water $(30: 70, v / v)$ containing $0.1 \%$ formic acid. The extract was filtered $(0.45-\mu \mathrm{m}$ Nylon filter) and diluted (1:5) before the UPLC system injection (ACQUITY, Waters). One nanograms per microliter of $\left[{ }^{2} \mathrm{H}_{6}\right]$-ABA (Gómez-Cadenas et al. 2002) was added as an internal standard.

An Excel 2 C18-AR column $(50 \times 2.1 \mathrm{~mm}$, ACE, UK) was used, and the temperature was set at $36{ }^{\circ} \mathrm{C}$. The mobile phase was composed of methanol $70 \%$ (solvent $\mathrm{A}$ ) and acetonitrile $90 \%$ (solvent B) which contain $0.1 \%$ formic acid. The solvent gradient was programmed to change linearly: 0-1 min, 100\% A; 1-2.5 min, 100-50\% A; 2.5-2.8 min, 50\% A; and 2.8$3 \mathrm{~min}, 100 \% \mathrm{~A}$, for $2 \mathrm{~min}$ equilibration prior to the next injection. The solvent flow rate and injection volume were set at $0.15 \mathrm{~mL} \mathrm{~min}^{-1}$ and $20 \mu \mathrm{L}$, respectively. 
Mass spectrometric analyses were performed by an ACQUITY Waters triple quadrupole mass spectrometer. The electrospray conditions were as follows: Polarity ES, capillary voltage $3.0 \mathrm{kV}$, source temperature $120^{\circ} \mathrm{C}$, desolvation gas temperature $350{ }^{\circ} \mathrm{C}$, cone gas flow $90 \mathrm{~L} \mathrm{~h}^{-1}$, and desolvation gas flow $900 \mathrm{~L} \mathrm{~h}^{-1}$. High-purity nitrogen was used as the nebulizer and auxiliary gas, and argon was used as the collision gas. Analysis of ABA was based on appropriate multiple reaction monitoring (MRM) mode: $\left[{ }^{2} \mathrm{H}_{6}\right] \mathrm{ABA}$ and ABA were monitored at $m / z$ transitions of $269 \rightarrow 159,225$, and $263 \rightarrow$ 153,219 , respectively. The cone voltage (V) and collision energies $(\mathrm{eV})$ were optimized to maximize the transition signals: $\left.{ }^{2} \mathrm{H}_{6}\right] \mathrm{ABA} 20 \mathrm{~V}$ and $12 \mathrm{eV}$, and ABA $15 \mathrm{~V}, 10 \mathrm{eV}$, and $12 \mathrm{eV}$. The raw data were acquired and processed with a MassLynx 4.1 software. Quantification was performed using calibration curves based on the $\left.\mathrm{ABA} /{ }^{2} \mathrm{H}_{6}\right] \mathrm{ABA}$ ratio of standard solutions.

\subsection{Quantification of proline, shikimic acid, and total polyphenols}

Needle proline contents were determined following the procedure of Bates et al. (1973). Fifty milligrams of lyophilized tissue was processed with $3 \%(w / v)$ sulfosalicylic acid, and an aliquot of the supernatant was colored by the addition of ninhydrin. The heated ninhydrin-proline complex $\left(100{ }^{\circ} \mathrm{C}\right.$, $1 \mathrm{~h}$ ) was mixed with $4 \mathrm{~mL}$ of toluene. The condensation product was measured spectrophotometrically at $520 \mathrm{~nm}$ (Shimadzu UV-1700). The proline concentration was calculated using a L-proline standard curve.

Shikimic acid was determined together with resin acids via the GC-MS analyses. Total polyphenol content was estimated in an aliquot of the extracts obtained to determine ABA. Two hundred milliliters was diluted with Milli-Q water and mixed with FolinCiocalteau reagent. The absorbance was measured at $725 \mathrm{~nm}$ (Velioglu et al. 1998). Results were expressed as milligrams of gallic acid equivalents (GAEs) per gram dry weight.

\subsection{Determination of physiological phases}

Three physiological phases (I, II, and III) were established to analyze the metabolic compounds extracted from the needles. To define the limits of each phase, we took the points of physiological change of the relationships between $\Psi_{\mathrm{pd}}$ and gas exchange $\left(g_{\mathrm{s}}\right.$ and $\left.A\right)$. The first limit $\left(\Psi_{\mathrm{pd}, 1}\right)$, between phases I and II, was defined as the change in the slope of the relationship between $\Psi_{\mathrm{pd}}$ and $g_{\mathrm{s}}$. $\Psi_{\mathrm{pd}, 1}$ was calculated as the join-point of a two-linear segmented model. This model is a non-linear model that fits a curve compound of two linear models with different slopes. The point at which the switch between the two functions occurs is generally called a jointpoint, which can easily be associated with a change in the trend of the studied variable (Schabenberger and Pierce
2002). The second limit $\left(\Psi_{\mathrm{pd}, 2}\right)$ was defined as the point where $A$ reached first time a value of zero since the application of the water deficit treatment. $\Psi_{\mathrm{pd}, 2}$ was calculated from a linear model adjusted to the relationship between $\Psi_{\mathrm{pd}}$ and $A$.

\subsection{Statistical analyses}

While the contents of proline, shikimic acid, and ABA were related directly to $\Psi_{\mathrm{pd}}$, terpenoid contents were grouped taking into account the delineation of the three phases. One-way ANOVAs were performed to compare the contents of the metabolic compounds between the different physiological phases (I, II, and III). Multiple comparisons were carried out among the different phases using the post hoc Tukey's honestly significant difference test. For a more concise view, a principal component analysis (PCA) was made with those metabolic compounds that changed statistically along the soil water deficit period. Data was expressed as means \pm standard error. Statistical analyses were carried out using SAS version 8.0 (SAS, Cary, NC, USA), and all statistical analyses were considered significant at $P<0.05$.

\section{Results}

\subsection{Physiological phases of water deficit development}

The relationship between predawn water potential $\left(\Psi_{\mathrm{pd}}\right)$ and stomatal conductance $\left(g_{\mathrm{s}}\right)$, fitted by a two-linear segmented model $\left(R^{2}=0.92, P<0.001\right)$, had a joint-point at ca. $-0.6 \mathrm{MPa}$ (Fig. 1a). For the $\Psi_{\mathrm{pd}}$ range of 0 to $-0.6 \mathrm{MPa}, g_{\mathrm{s}}$ steeply decreased from maximum values of $500 \mathrm{mmol}$ $\mathrm{H}_{2} \mathrm{O} \mathrm{m}^{-2} \mathrm{~s}^{-1}$ to values around $150 \mathrm{mmol} \mathrm{H}_{2} \mathrm{O} \mathrm{m}^{-2} \mathrm{~s}^{-1}$. For $\Psi_{\mathrm{pd}}$ values lower than $-0.6 \mathrm{MPa}, g_{\mathrm{s}}$ decreased with a smaller slope towards values of $50-20 \mathrm{mmol} \mathrm{H}_{2} \mathrm{O} \mathrm{m}^{-2} \mathrm{~s}^{-1}$. The linear relationship between net $\mathrm{CO}_{2}$ uptake $(A)$ and $\Psi_{\mathrm{pd}}\left(R^{2}=0.87\right.$, $P<0.001$ ) (Fig. 1b) showed a constant decrease in $A$ from maximum values around $12 \mu \mathrm{mol} \mathrm{CO} \mathrm{CO}^{-2} \mathrm{~s}^{-1}$ to zero value at ca. $-1.8 \mathrm{MPa}$. Thus, $\Psi_{\mathrm{pd}}$ and gas exchange characteristics suggested the existence of two key physiological modifications along the decrease in soil water availability in P. sylvestris. The first one was at $\Psi_{\mathrm{pd}, 1}=-0.6 \mathrm{MPa}$, at which point the rate of decrease in $g_{\mathrm{s}}$ with $\Psi_{\mathrm{pd}}$ changed, and the second one was at $\Psi_{\mathrm{pd}, 2}=-1.8 \mathrm{MPa}$, where photosynthesis reached values of zero. These two criteria were used to define the three physiological phases of soil water deficit development: phase I $\left(\Psi_{\mathrm{pd}}>-0.6 \mathrm{MPa}\right)$, denoting a mild water deficit; phase II $\left(-0.6>\Psi_{\mathrm{pd}}>-1.8 \mathrm{MPa}\right)$, denoting a moderate water deficit with significantly reduced values of $g_{\mathrm{s}}$ and $A$; and phase III $\left(-1.8>\Psi_{\mathrm{pd}}>-2.4 \mathrm{MPa}\right)$, denoting a severe water deficit with completely suppressed photosynthesis. For the control trees, the average ( $\pm \mathrm{SE}$ ) values of $\Psi_{\mathrm{pd}}, g_{\mathrm{s}}$, and $A$ observed through the experiment were $-0.39 \pm 0.01 \mathrm{MPa}$, 


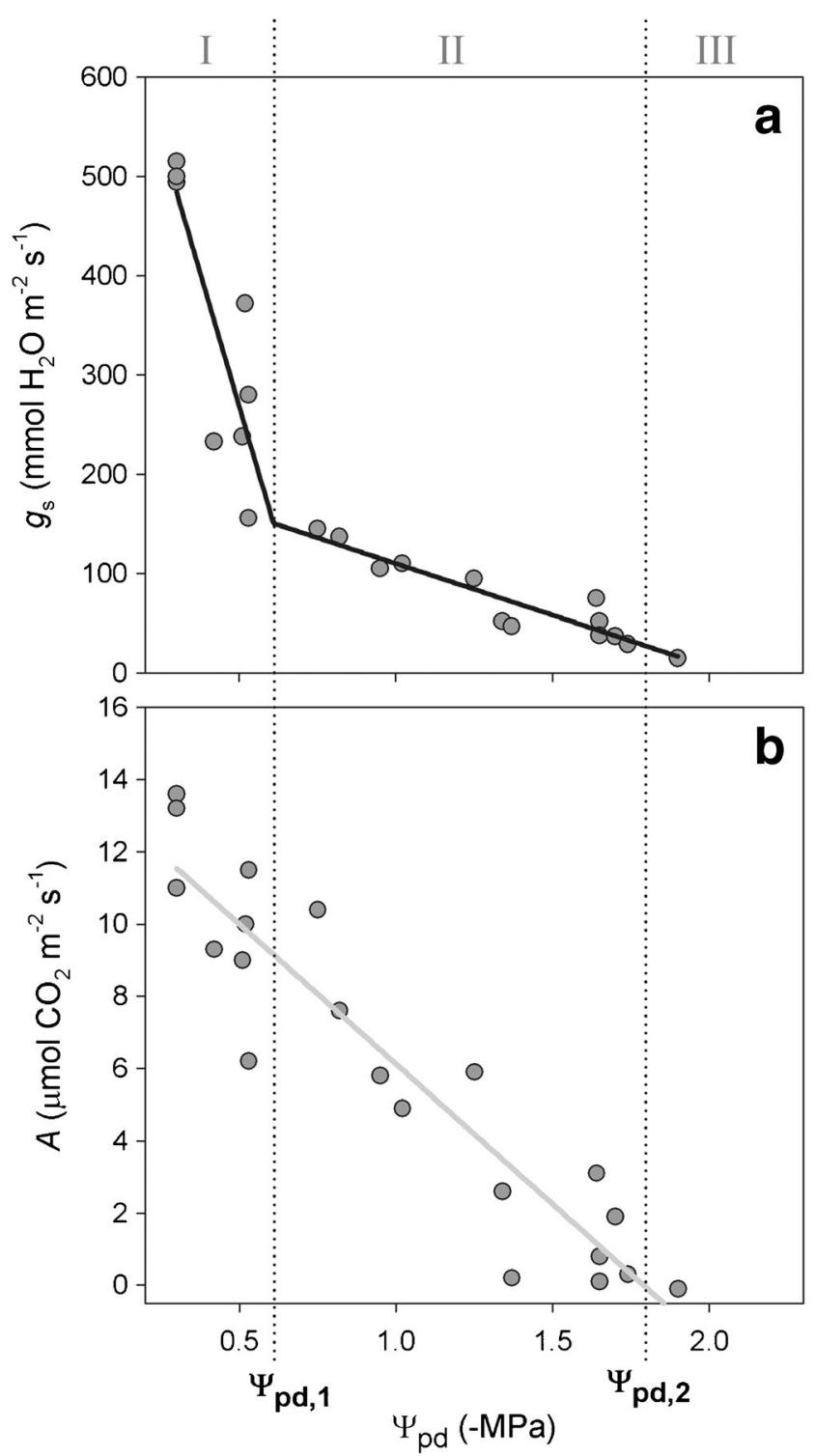

Fig. 1 Relationships of predawn shoot water potential $\left(\Psi_{\mathrm{pd}}\right)$ with stomatal conductance $\left(g_{\mathrm{s}}\right)$ (a) and with net $\mathrm{CO}_{2}$ uptake $(A)(\mathbf{b})$ measured in five Scots pines along a water deficit period. $I-I I I$ : physiological phases considered. $\Psi_{p d, 1}$ : limit between phases I and II defined as the change in the slope of the relationship between $\Psi_{\mathrm{pd}}$ and $g_{s} . \Psi_{p d, 2}$ : limit between phases II and III defined as the point where $A$ is zero

$397 \pm 15 \mathrm{mmol} \mathrm{H}_{2} \mathrm{O} \mathrm{m}^{-2} \mathrm{~s}^{-1}$, and $11.1 \pm 0.2 \mu \mathrm{mol}$ $\mathrm{CO}_{2} \mathrm{~m}^{-2} \mathrm{~s}^{-1}$, respectively.

\subsection{Modification of needle secondary metabolism through the water deficit phases}

Average contents of most monoterpenes and sesquiterpenoids increased with increasing the severity of water deficit (Table 1), except for a few compounds (e.g., sabinene or $\gamma$ muurolene) that did not vary significantly among the phases (Table 1). The statistical analysis revealed significant differences in the content of volatile terpenes (e.g., $\alpha$-pinene, limonene, or $\beta$-caryophyllene) already between phases I and II $(P<0.05)$. In contrast, the content of resin acids tended to decrease throughout the phases (Table 1). This apparent decrease was statistically significant $(P<0.05)$ for three of the seven resin acids analyzed (palustric, levopimaric, and neoabietic acids). For all terpenoids, mean values of control trees did not differ significantly from the averages of the water-deficient trees at phase I (Table 1).

During water deficit phases I and II, proline and shikimic acid remained practically constant with mean values around $0.35 \mu \mathrm{mol} \mathrm{g}^{-1}$ and $0.82 \mathrm{mg} \mathrm{g}^{-1}$, respectively. In phase III, needle proline and shikimic acid content rose up to mean values of $1.24 \pm 0.06 \mu \mathrm{mol} \mathrm{g}^{-1}$ and $2.40 \pm 0.12 \mathrm{mg} \mathrm{g}^{-1}$ respectively, i.e., ca. threefold higher than the mean values for phases I and II (Fig. 2a, b). There was no significant effect of soil water deficit treatment on total polyphenol content (Fig. 2b). Abscisic acid (ABA) content was statistically invariable (around $1.0 \mu \mathrm{g} \mathrm{g}^{-1}$ ) for a $\Psi_{\text {pd }}$ range of 0 to $-1.3 \mathrm{MPa}$. Beyond $-1.3 \mathrm{MPa}$, ABA content started to increase exponentially (Fig. 2c). ABA content reached at the end of phase II $2.8 \pm 0.5 \mu \mathrm{g} \mathrm{g}^{-1}$ and in phase III $11.7 \pm 0.0 \mu \mathrm{g} \mathrm{g}^{-1}$ (both statistically different from the initial values, $P<0.05)$. Control trees had mean values of proline, shikimic acid, and ABA of $0.38 \pm 0.02 \mu \mathrm{mol} \mathrm{g}^{-1}$, $0.61 \pm 0.07 \mathrm{mg} \mathrm{g}^{-1}$, and $0.73 \pm 0.15 \mu \mathrm{g} \mathrm{g}^{-1}$, respectively, through the experimental period. These control values were not statistically different from the mean values of waterdeficient trees at phases I and II, but they were significantly lower than those at phase III $(P<0.05)$.

A PCA based on those compounds that changed statistically along the water deficit period (monoterpenes and sesquiterpenoids, proline, shikimic acid, and ABA) indicated that the first and second axes accounted for 56 and $29 \%$ of the total variation, respectively (Fig. 3). While we detected a segregation between the three physiological phases established (I-III), values of control trees were not segregated from the values of phase I (Fig. 3).

\section{Discussion}

\subsection{Soil water deficit severity in Pinus sylvestris: mild water deficit primarily alters photosynthetic characteristics}

Modifications in needle predawn water potential and gas exchange characteristics defined two important physiological thresholds during the water deficit period of $P$. sylvestris. The first threshold was obtained at $-0.6 \mathrm{MPa}$ and about $70 \%$ of stomatal closure (Fig. 1a). The second threshold was observed at $-1.8 \mathrm{MPa}$, where plants reached a zero net $\mathrm{CO}_{2}$ uptake. The first, mild water deficit phase ( $\Psi_{\text {pd }}$ range from 0 to $-0.6 \mathrm{MPa}$ ) was characterized by significant reductions in stomatal conductance (from 500 to $150 \mathrm{mmol}$ 
Table 1 Average $( \pm \mathrm{SE})$ concentrations $\left(\mu \mathrm{g} \mathrm{g}^{-1}\right)$ of monoterpenes, sesquiterpenoids, and resin acids of three control trees and five water deficiencytreated trees during three physiological phases (I-III)

\begin{tabular}{|c|c|c|c|c|c|}
\hline & \multirow[t]{2}{*}{ Terpene } & \multirow[t]{2}{*}{ Control trees } & \multicolumn{3}{|c|}{ Water-deficient trees } \\
\hline & & & $\begin{array}{l}\mathrm{I} \\
\Psi_{\mathrm{pd}}>-0.6\end{array}$ & $\begin{array}{l}\text { II } \\
-0.6>\Psi_{\mathrm{pd}}>-1.8\end{array}$ & $\begin{array}{l}\text { III } \\
-1.8>\Psi_{\mathrm{pd}}>-2.4\end{array}$ \\
\hline \multirow{12}{*}{$\begin{array}{l}\text { Monoterpenes } \\
\left(\mu g^{-1}\right)\end{array}$} & Tricyclene & $21.4 \pm 1.5 \mathrm{a}$ & $23.3 \pm 2.3 \mathrm{a}$ & $35.3 \pm 3.9 b$ & $44.9 \pm 6.4 b$ \\
\hline & $\alpha$-Thujene & $1.10 \pm 0.09 \mathrm{a}$ & $1.19 \pm 0.12 \mathrm{a}$ & $1.83 \pm 0.17 \mathrm{~b}$ & $2.41 \pm 0.31 \mathrm{c}$ \\
\hline & $\alpha$-Pinene & $275 \pm 18 \mathrm{a}$ & $266 \pm 24 a$ & $456 \pm 67 b$ & $528 \pm 98 b$ \\
\hline & Camphene & $49.8 \pm 3.9 \mathrm{a}$ & $53.9 \pm 5.6 \mathrm{a}$ & $76.8 \pm 69.0 \mathrm{~b}$ & $94.4 \pm 13.0 \mathrm{~b}$ \\
\hline & Sabinene & $4.7 \pm 0.5 \mathrm{a}$ & $4.6 \pm 0.6 \mathrm{a}$ & $5.78 \pm 0.72 \mathrm{a}$ & $6.84 \pm 1.02 \mathrm{a}$ \\
\hline & $\beta$-Pinene & $29.0 \pm 2.1 \mathrm{a}$ & $47.1 \pm 7.4 \mathrm{ab}$ & $62.3 \pm 8.6 b$ & $66.3 \pm 14.6 b$ \\
\hline & Myrcene & $19.9 \pm 1.8 \mathrm{a}$ & $19.2 \pm 2.2 \mathrm{a}$ & $30.3 \pm 3.4 b$ & $39.7 \pm 5.5 b$ \\
\hline & $\alpha$-Phellandrene & $0.49 \pm 0.04 \mathrm{a}$ & $0.44 \pm 0.06 \mathrm{a}$ & $0.84 \pm 0.11 b$ & $1.15 \pm 0.21 b$ \\
\hline & Limonene & $5.22 \pm 0.50 \mathrm{a}$ & $5.63 \pm 0.71 \mathrm{a}$ & $11.1 \pm 1.52 b$ & $11.2 \pm 1.92 b$ \\
\hline & (Z)- $\beta$-Ocimene & $0.57 \pm 0.05 \mathrm{a}$ & $0.55 \pm 0.08 \mathrm{a}$ & $1.23 \pm 0.29 b$ & $1.07 \pm 0.17 \mathrm{~b}$ \\
\hline & (E)- $\beta$-Ocimene & $5.66 \pm 0.53 \mathrm{a}$ & $7.55 \pm 1.40 \mathrm{ab}$ & $11.12 \pm 1.52 b$ & $11.94 \pm 2.25 b$ \\
\hline & Terpinolene & $0.39 \pm 0.04 \mathrm{a}$ & $0.42 \pm 0.05 \mathrm{a}$ & $1.23 \pm 0.29 b$ & $1.29 \pm 0.46 b$ \\
\hline \multirow{14}{*}{$\begin{array}{l}\text { Sesquiterpenoids } \\
\qquad\left(\mu \mathrm{g} \mathrm{g}^{-1}\right)\end{array}$} & $\beta$-Elemene & $0.93 \pm 0.08 \mathrm{a}$ & $1.01 \pm 0.11 \mathrm{ab}$ & $1.46 \pm 0.19 b c$ & $1.68 \pm 0.28 \mathrm{c}$ \\
\hline & $\beta$-Caryophyllene & $11.7 \pm 0.5 \mathrm{a}$ & $8.8 \pm 0.6 \mathrm{a}$ & $14.0 \pm 1.9 \mathrm{~b}$ & $17.1 \pm 2.5 b$ \\
\hline & $\beta$-Copaene & $0.078 \pm 0.007 \mathrm{a}$ & $0.072 \pm 0.009 \mathrm{a}$ & $0.20 \pm 0.06 b$ & $0.15 \pm 0.103 \mathrm{ab}$ \\
\hline & Aromadendrene & $0.047 \pm 0.005 \mathrm{a}$ & $0.057 \pm 0.015 \mathrm{a}$ & $0.18 \pm 0.04 b$ & $0.26 \pm 0.081 \mathrm{~b}$ \\
\hline & $\alpha$-Humulene & $5.01 \pm 0.22 \mathrm{a}$ & $4.25 \pm 0.23 \mathrm{a}$ & $7.23 \pm 1.06 \mathrm{~b}$ & $8.70 \pm 1.485 b$ \\
\hline & $\gamma$-Muurolene & $0.54 \pm 0.05 \mathrm{a}$ & $0.48 \pm 0.06 \mathrm{a}$ & $1.63 \pm 0.53 \mathrm{a}$ & $1.47 \pm 0.95 \mathrm{a}$ \\
\hline & Germacrene D & $20.7 \pm 1.6 \mathrm{a}$ & $16.0 \pm 1.9 \mathrm{a}$ & $26.2 \pm 5.9 \mathrm{a}$ & $20.7 \pm 9.3 \mathrm{a}$ \\
\hline & $\beta$-Selinene & $0.28 \pm 0.02 \mathrm{a}$ & $0.37 \pm 0.09 \mathrm{a}$ & $0.77 \pm 0.14 b$ & $1.03 \pm 0.283 b$ \\
\hline & Bicyclogermacrene & $0.25 \pm 0.02 \mathrm{a}$ & $0.23 \pm 0.02 \mathrm{a}$ & $0.51 \pm 0.11 b$ & $0.60 \pm 0.22 b$ \\
\hline & $\alpha$-Muurolene & $0.72 \pm 0.05 \mathrm{a}$ & $0.71 \pm 0.08 \mathrm{a}$ & $0.99 \pm 0.10 \mathrm{~b}$ & $1.04 \pm 0.155 b$ \\
\hline & $\gamma$-Cadinene & $0.64 \pm 0.05 \mathrm{a}$ & $0.73 \pm 0.09 \mathrm{a}$ & $1.73 \pm 0.40 \mathrm{~b}$ & $1.97 \pm 0.678 \mathrm{~b}$ \\
\hline & $\delta$-Cadinene & $0.42 \pm 0.03 \mathrm{a}$ & $0.54 \pm 0.06 \mathrm{a}$ & $1.26 \pm 0.30 \mathrm{~b}$ & $1.54 \pm 0.58 b$ \\
\hline & Germacrene D-4-ol & $0.54 \pm 0.08 \mathrm{a}$ & $0.62 \pm 0.10 \mathrm{a}$ & $0.95 \pm 0.13 b$ & $0.94 \pm 0.180 \mathrm{~b}$ \\
\hline & $\alpha$-Cadinol & $0.15 \pm 0.01 \mathrm{a}$ & $0.25 \pm 0.02 \mathrm{a}$ & $0.42 \pm 0.10 \mathrm{a}$ & $0.43 \pm 0.149 a$ \\
\hline \multirow{7}{*}{$\begin{array}{l}\text { Resin acids } \\
\qquad\left(\mu g g^{-1}\right)\end{array}$} & Pimaric acid & $81 \pm 8 \mathrm{a}$ & $100 \pm 11 \mathrm{a}$ & $91 \pm 10 \mathrm{a}$ & $89 \pm 17 a$ \\
\hline & Isopimaric acid & $22 \pm 2 \mathrm{a}$ & $24 \pm 4 a$ & $22 \pm 3 a$ & $23 \pm 3 a$ \\
\hline & Palustric acid & $175 \pm 18 \mathrm{a}$ & $195 \pm 38 \mathrm{a}$ & $91 \pm 17 b$ & $25 \pm 8 \mathrm{c}$ \\
\hline & Levopimaric acid & $513 \pm 34 a$ & $606 \pm 62 a$ & $405 \pm 62 \mathrm{a}$ & $152 \pm 35 b$ \\
\hline & Dehydroabietic acid & $667 \pm 43 \mathrm{a}$ & $743 \pm 102 a$ & $747 \pm 77 \mathrm{a}$ & $730 \pm 84 a$ \\
\hline & Abietic acid & $183 \pm 12 \mathrm{a}$ & $205 \pm 24 a$ & $178 \pm 23 \mathrm{a}$ & $138 \pm 22 \mathrm{a}$ \\
\hline & Neoabietic acid & $2007 \pm 213 a$ & $2608 \pm 469 a$ & $1495 \pm 206 b$ & $523 \pm 143 c$ \\
\hline
\end{tabular}

Phases are defined according to changes in predawn water potential $\left(\Psi_{\mathrm{pd}}\right)$, stomatal conductance, and net assimilation rate (Fig. 1). Compounds in each group are arranged according to their retention time, from shortest to longest. Lowercase letters indicate statistically significant differences (Tukey test, $P<0.05)$ in compound contents among the phases

$\mathrm{H}_{2} \mathrm{Om}^{-2} \mathrm{~s}^{-1}$ ) with moderate changes in photosynthesis rates overa very narrow range of $\Psi_{\mathrm{pd}}$ (Fig. 1). These physiological changes would have induced at the end of phase I, a significant reduction of plant transpiration and a higher instantaneous water use efficiency. Additionally, the strong decrease in stomatal conductance over a very narrow range of $\Psi_{\mathrm{pd}}$ has been reported previously in Pinus radiata and interpreted as an evidence of strongly isohydric stomatal response to water deficit (Brodribb and McAdam 2013).
During the mild phase, the average values of all metabolite contents did not significantly differ from those in control trees.

\subsection{Moderate soil water deficit induces changes in needle secondary metabolism}

Phase II $\left(-0.6>\Psi_{\mathrm{pd}}>-1.8 \mathrm{MPa}\right)$ was characterized by strongly reduced stomatal conductance (below $150 \mathrm{mmol} \mathrm{H}_{2} \mathrm{O} \mathrm{m}^{-2} \mathrm{~s}^{-1}$ ) 


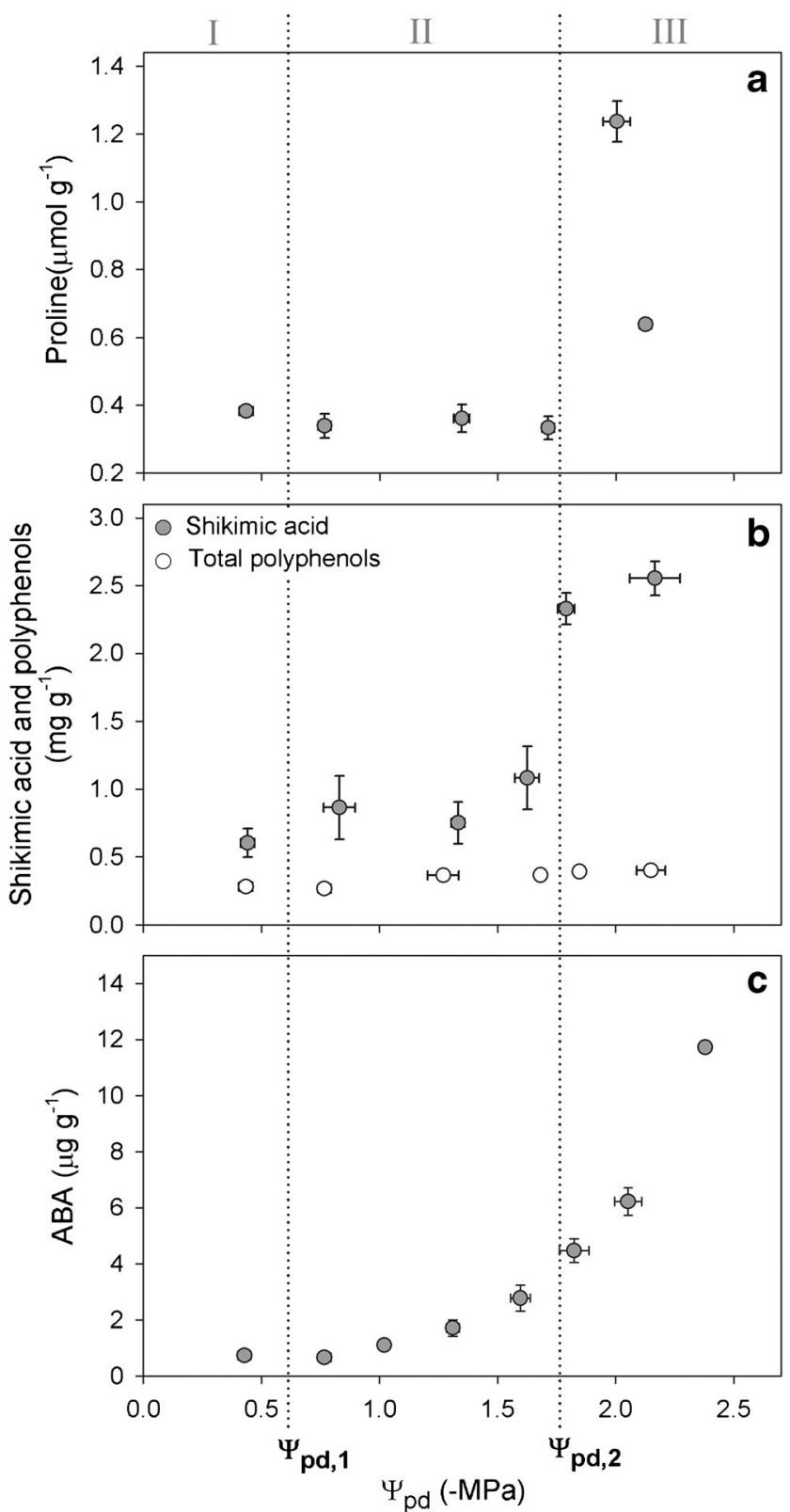

Fig. 2 Relationships between predawn shoot water potential $\left(\Psi_{\mathrm{pd}}\right)$ and average $( \pm \mathrm{SE})$ contents of proline $(\mathbf{a})$, shikimic acid and total polyphenols (b), and abscisic acid (ABA) (c) in needles of five waterdeficient Scots pines. $\Psi_{p d, 1}, \Psi_{p d, 2}$, and dotted lines indicate the limits of the three physiological phases considered $\left(I, \Psi_{\mathrm{pd}}>-0.6 \mathrm{MPa} ; I I\right.$, $-0.6>\Psi_{\mathrm{pd}}>-1.8 \mathrm{MPa}$; and III, $\left.-1.8>\Psi_{\mathrm{pd}}>-2.4 \mathrm{MPa}\right)$

and net $\mathrm{CO}_{2}$ uptake rate (from 9 to $0 \mu \mathrm{molCO}_{2} \mathrm{~m}^{-2} \mathrm{~s}^{-1}$ ) (Fig. 1). At this stage, trees started to accumulate most of the volatile terpenoids analyzed (monoterpenes and sesquiterpenoids). As stomatal aperture cannot significantly control the emissions of hydrophobic compounds (Niinemets and Reichstein 2003), the accumulation of these volatile terpenes (although mostly stored in the resin ducts) cannot be explained by massive reductions in stomatal closure and rather suggests an increment in their synthesis. Such an increment has been reported in several cases in

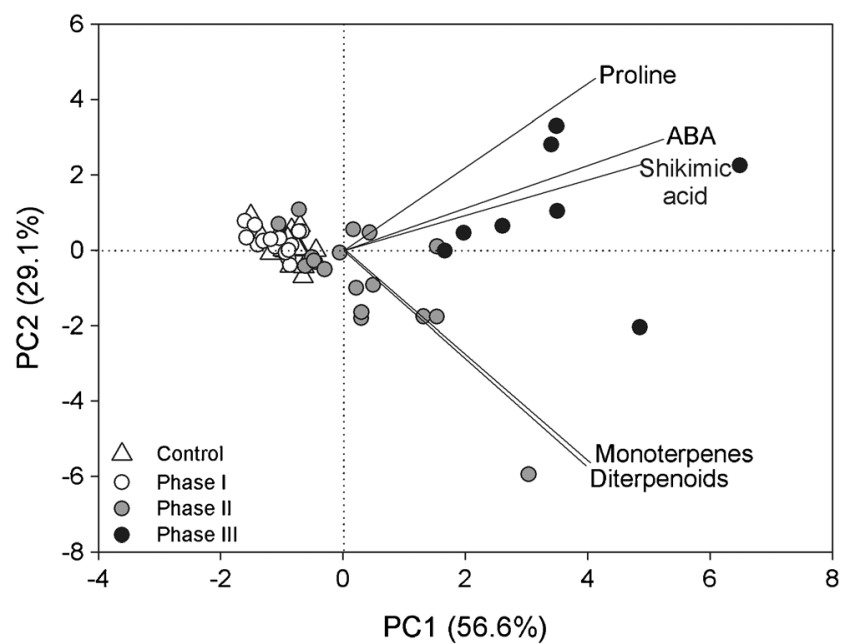

Fig. 3 Relationship between the first two principal components ( $\mathrm{PC} 1 \mathrm{vs.}$ PC2) of the principal component analysis (PCA) computed on needle metabolic compound variation. Symbols correspond to control (triangle) or water-deficient trees (circle) and are color-coded according to each physiological phase: I, white; II, gray; III, black

plants treated with a water deficiency (Lluisà and Peñuelas 1998) and suggested to reflect changes in the source/sink balance due to inhibition of growth (Lerdau et al. 1994; Constable et al. 1999). Indeed, this level of moderate soil water deficit usually substantially decreases the growth of conifers (e.g., Turtola et al. 2003) and can lead to shifts in the translocation of the carbon fixed in photosynthesis to the formation of secondary compounds (Lorio and Sommers 1986; Turtola et al. 2003; McDowell 2011; Niinemets 2016). From an ecological perspective, greater contents of monoterpenes and sesquiterpenoids could enhance the tree resistance to herbivory and pathogens (Litvak and Monson 1998; Cheng et al. 2007).

Regarding resin acids, two of them, palustric and neoabietic acid, decreased analogously as the observations of Hodges and Lorio (1975) on Pinus taeda xylem oleoresin. Other studies had also reported variations in the concentration of wood resin acids with increasing the severity of water deficit (Turtola et al. 2003) or an increase in resin acids in needles after the onset of a water stress decay process (Sanz et al. 2014). However, to the best of our knowledge, no studies have reported a decrease in resin acids in conifer needles during a water deficit period. Such a decrease might reflect reprogramming of the defense metabolite pathway between syntheses of larger (resin acids) and smaller (monoterpenoids) plastidial isoprenoids, but so far, the way such metabolic regulation could occur is not known (Rajabi Memari et al. 2013). Terpenoids are components of constitutive defenses against pests and pathogens with non-volatile resin acids involved in direct defenses (reducing palatability for herbivores and sealing wound sites) (Hodges and Lorio 1975; Wainhouse 2004) and with more volatile monoterpenes and sesquiterpenoids involved in both direct (reducing palatability and serving as herbivore repellents) and indirect defenses 
(signals for herbivore enemies) (Lewinsohn et al. 1993; Litvak and Monson 1998). Thus, changes in the composition of terpenoids can importantly modify the needle capacity for direct and indirect defenses.

Finally, the slight increase of ABA observed at the end of phase II (Fig. 2c) indicated the beginning of the contribution of ABA in stomatal closure. In order to reduce water loss in the plant, ABA affects guard cells by inducing osmotic efflux and therefore turgor loss and reduction of stomatal aperture. Stomatal closure detected before ABA concentration rising may respond only to the change in water potential at the leaf level (Buckley 2005; Brodribb and McAdam 2013).

\subsection{Severe soil water deficit effects on needle secondary metabolism}

Under severe soil water deficit, in phase III $\left(-1.8>\Psi_{\text {pd }}>-2.4 \mathrm{MPa}\right)$ characterized by minimum values of stomatal conductance and zero or close to zero net $\mathrm{CO}_{2}$ uptake (Fig. 1), there was a sudden increase in the concentration of proline, shikimic acid, and ABA. The accumulation of proline in phase III confirms the suggestion that $P$. sylvestris was under a severe soil water deficit stress (Vilagrosa et al. 2010). On the other hand, the carbon fixed during phase II under a moderate water deficit could also be used in phase III for synthesis of shikimic acid, one of the key sources of carbon for defense instead of growth (Becerra-Moreno et al. 2015). Regarding the rapid increase in foliar ABA levels, Brodribb and McAdam (2013) suggested that such a major increase results in complete stomatal closure and drastic reduction of water loss. Both strategies, the increase of defense compounds and the prevention of desiccation by stomatal closure, would benefit the tree during a short time period. If water deficit persists, with zero or close to zero photosynthetic carbon uptake and a continuous demand for carbohydrates to produce secondary compounds and to maintain metabolism, the carbohydrate reserves will be depleted, leading eventually to starvation or an inability to cope with biotic attacks (McDowell 2011). However, the time it takes to succumb to water deficit will ultimate depend on the size of the reserve pools (Niinemets 2010).

Nevertheless, contrary to shikimic acid, total polyphenol content was unaffected in the water potential range of our experiment. Given that polyphenols are derived from shikimic acid, and as the shikimic acid content did not change significantly until leaf water potential was less than $-1.8 \mathrm{MPa}$, there is still a possibility that an increase in total needle polyphenol content could occur at more negative water potential values than the ones reached in this study. Alternatively, enhanced shikimic acid contents might reflect increased transformation of shikimic acid into lignin (Becerra-Moreno et al. 2015) as observed in Pinus canariensis (Grill et al. 2004). This could serve as a mechanical barrier against pathogens (Monties and Fukushima 2001). In addition, more strongly lignified cell walls can enhance needle mechanical resistance avoiding collapse under excess water stress (Cochard et al. 2004) and have a greater change in water potential for a given change in needle water content, thereby allowing for extraction of water from drier soil (Niinemets 2001). Further studies looking into lignin formation and changes in needle water extraction capacity are necessary to test these hypotheses.

Finally in phase III, the concentration of most volatile terpenes that had increased significantly in phase II remained statistically constant, while the concentration of some resin acids (palustric, levopimaric, and neoabietic acid) kept decreasing significantly, which might be a continuation of the reprogramming process of the defense metabolite pathway which started in phase II.

\section{Conclusion}

This study establishes a direct correspondence between physiological parameters and secondary metabolites through their simultaneous measurements along a soil water deficit period. Our results allowed the distinction of clearly physiological phases in response to water deficit evolution. In this way, a moderate water deficit (phase II) would be associated to increased levels of needle volatile terpenes with respect to phase I, whereas a severe water deficit (phase III) would be associated to an increment in proline, shikimic acid, or ABA. Although there are biochemical processes related to secondary metabolism and plant-pathogen relations that are still poorly understood and deserve further investigations, this work confirms that most of the secondary metabolites did not increase until the plant was under a moderate to severe water deficit.

Acknowledgements We thank Pilar Hijazo for the valuable help in the laboratory during the extraction and quantification processes of the metabolic compounds.

\section{Compliance with ethical standards}

Funding Work of DSK is supported by a DOC INIA contract cofunded by INIA and ESF. This study was supported by Gobierno de Aragón (research group H38).

\section{References}

Adams RP (2009) Identification of essentials oil components by gas chromatography/mass spectrometry, 4th edn. Alluredbooks, Carol Stream, IL, p 5

Bates SL, Waldre RP, Teare ID (1973) Rapid determination of free proline for water-stress studies. Plant Soil 39:205-207

Becerra-Moreno A, Redondo-Gil M, Benavides J, Nair V, CisnerosZevallos L, Jacobo-Velázquez DA (2015) Combined effect of water loss and wounding stress on gene activation of metabolic pathways associated with phenolic biosynthesis in carrot. Front Plant Sci 6:837

Brodribb TJ, McAdam SAM (2013) Abscisic acid mediates a divergence in the drought response of two conifers. Plant Physiol 162:1370-1377 
Buckley TN (2005) The control of stomata by water balance. New Phytol 168:275-292

Cheng AX, Lou YG, Mao YB, Lu S, Wang J, Chen XY (2007) Plant terpenoids: biosynthesis and ecological functions. J Integr Plant Biol 49:179-186

Cochard H, Froux F, Mayr S, Coutand C (2004) Xylem wall collapse in water-stressed pine needles. Plant Physiol 134:401-408

Constable JVH, Litvak ME, Greenberg JP, Monson RK (1999) Monoterpene emission from coniferous trees in response to elevated $\mathrm{CO}_{2}$ concentration and climate warming. Glob Chang Biol 5:255-267

Corcuera L, Gil-Pelegrin E, Notivol E (2012) Aridity promotes differences in proline and phytohormone levels in Pinus pinaster populations from contrasting environments. Trees 26:799-808

Galiano L, Martínez-Vilalta J, Lloret F (2010) Drought-induced multifactor decline of Scots pine in the Pyrenees and potential vegetation change by the expansion of co-occurring oak species. Ecosystems 13:978-991

Gamir J, Pastor V, Kaever A, Cerezo M, Flors V (2014) Targeting novel chemical and constitutive primed metabolites against Plectosphaerella cucumerina. Plant J 78:227-240

Gómez-Cadenas A, Pozo OJ, García-Agustín P, Sancho JV (2002) Direct analysis of abscisic acid in crude plant extracts by liquid chromatography-electrospray/tandem mass spectrometry. Phytochem Anal 13:228-234

Gref R, Ericsson A (1985) Wound-induced changes of resin acid concentrations in living bark of Scots pine seedlings. Can J For Res 15:92-96

Grill D, Tausz M, Pöllinger U, Jiménez M, Morales D (2004) Effects of drought on needle anatomy of Pinus canariensis. Flora 199:85-89

Hodges JD, Lorio PL (1975) Moisture stress and composition of xylem oleoresin in loblolly pine. For Sci 21:283-290

Karanikas C, Walker V, Scaltsoyiannes A, Comte G, Bertrand C (2010) High vs. low yielding oleoresin Pinus halepensis Mill. Trees GC terpenoids profiling as diagnostic tool. Ann For Sci 67:412

Lerdau M, Litvak M, Monson R (1994) Monoterpenes and the growthdifferentiation balance hypothesis. Trends Ecol Evol 9:58-61

Lewinsohn E, Gijzen M, Muzika RM, Barton K, Croteau R (1993) Oleoresinosis in grand fir (Abies grandis) saplings and mature trees - modulation of this wound response by light and water stresses. Plant Physiol 101:1021-1028

Lindner M, Maroschek M, Netherer S, Kremer A, Barbati A, García-Gonzalo J, Seidl R, Delzon S, Corona P, Kolström M, Lexer MJ, Marchetti M (2010) Climate change impacts, adaptive capacity, and vulnerability of European forest ecosystems. Forest Ecol Manag 259:698-709

Litvak ME, Monson RK (1998) Patterns of induced and constitutive monoterpene production in conifer needles in relation to insect herbivory. Oecologia 114:531-540

Lluisà J, Peñuelas J (1998) Changes in terpene content and emission in potted Mediterranean woody plants under severe drought. Can J Bot 76:1366-1373

Lorio PL, Sommers RA (1986) Evidence of competition for photosynthates between growth processes and oleoresin synthesis in Pinus taeda L. Tree Physiol 2:301-306

Martínez-Vilalta J, Lloret F, Breshears DD (2012) Drought-induced forest decline: causes, scope and implications. Biol Lett 8:689-691

Matías L, Jump AS (2012) Interactions between growth, demography and biotic interactions in determining species range limits in a warming world: the case of Pinus sylvestris. Forest Ecol Manag 282:10-22

McDowell NG (2011) Mechanisms linking drought, hydraulics, carbon metabolism, and vegetation mortality. Plant Physiol 155:1051-1059

Monties B, Fukushima K (2001) Occurrence, function and biosynthesis of lignin. In: Hofrichter M, Steinbuchel A (eds) Biopolymers, volumen 1: lignin humic substances and coal. Wiley, Weinheim, pp 1-64

Moreira X, Sampedro L, Zas R (2009) Defensive responses of Pinus pinaster seedlings to exogenous application of methyljasmonate: concentration effect and systemic response. Environ Exp Bot 67:94-100

Munné-Bosch S, Falara V, Pateraki I, López-Carbonell M, Cela J, Kanellis AK (2009) Physiological and molecular responses of the isoprenoid biosynthetic pathway in a drought-resistant Mediterranean shrub, Cistus creticus exposed to water deficit. J Plant Physiol 166:136-145

Niinemets Ü (2001) Global-scale climatic controls of leaf dry mass per area, density, and thickness in trees and shrubs. Ecology 82:453-469

Niinemets Ü (2010) Responses of forest trees to single and multiple environmental stresses from seedlings to mature plants: past stress history, stress interactions, tolerance and acclimation. Forest Ecol Manag 260:1623-1639

Niinemets U (2016) Uncovering the hidden facets of drought stress: secondary metabolites make the difference. Tree Physiol 36:129-132

Niinemets Ü, Keenan TF (2014) Photosynthetic responses to stress in Mediterranean evergreens: mechanisms and models. Environ Exp Bot 103:24-41

Niinemets Ü, Reichstein M (2003) Controls on the emission of plant volatiles through stomata: sensitivity or insensitivity of the emission rates to stomatal closure explained. J Geophys Res-Atmos 108:4208

Peguero-Pina JJ, Alquézar-Alquézar JM, Mayr S, Cochard H, GilPelegrín E (2011) Embolism induced by winter drought may be critical for the survival of Pinus sylvestris L. near its southern distribution limit. Ann For Sci 68:565-574

Pureswaran DS, Gries R, Borden JH (2004) Quantitative variation in monoterpenes in four species of conifers. Biochem System Ecol 32:1109-1136

Rajabi Memari H, Pazouki L, Niinemets Ü (2013) The biochemistry and molecular biology of volatile messengers in trees. In: Niinemets Ü, Monson RK (eds) Biology, controls and models of tree volatile organic compound emissions. Springer, Berlin, pp 47-93

Sanz MA, Sánchez J, Camarero JJ, Peguero-Pina JJ, SanchoKnapik D, Gil-Pelegrín E (2014) Change in the terpenoid profile and secondary growth in declining stands of Pinus sylvestris $\mathrm{L}$. under Mediterranean influence as a response to local factors. Pirineos 169:e003

Schabenberger O, Pierce FJ (2002) Contemporary statistical models for the plant and soil sciences. CRC Press, Boca Raton, pp 252-259

Schafellner C, Berger R, Dermutz A, Führer E, Mattanovich J (1999) Relationship between foliar chemistry and susceptibility of Norway spruce Pinaceae to Pristiphora abietina (hymenoptera: tenthredinidae). Can Entomol 131:373-385

Schulze ED (1991) Water and nutrient interactions with plant water stress. In: Mooney HA, Winner WE, Pell EJ, Chu E (eds) Response of plants to multiple stresses. Academic Press, San Diego, California, pp 89-101

Tardieu F, Zhang J, Katerji N, Bethenod O, Palmer S, Davies WJ (1992) Xylem ABA controls the stomatal conductance of field grown maize subjected to soil compaction or soil drying. Plant Cell Environ 15:193-197

Teskey RO, Bongarten BC, Cregg BM, Dougherty PM, Hennessey TC (1987) Physiology and genetics of tree growth response to moisture and temperature stress: an examination of the characteristics of loblolly pine (Pinus taeda L.) Tree Physiol 3:41-61

Turner NC (1988) Measurement of plant water status by pressure chamber technique. Irrigation Sci 9:289-308

Turtola S, Manninen AN, Rikala R, Kainulainen P (2003) Drought stress alters the concentration of wood terpenoids in Scots pine and Norway spruce seedlings. J Chem Ecol 29:1981-1994

Velioglu YS, Mazza G, Gao L, Oomah BD (1998) Antioxidant activity and total phenolics in selected fruits, vegetables, and grain products. J Agric Food Chem 46:4113-4117

Verbruggen N, Hermans C (2008) Proline accumulation in plants: a review. Amino Acids 35:753-759

Vilagrosa A, Morales F, Abadía A, Bellot J, Cochard H, Gil-Pelegrín E(2010) Are symplast tolerance to intense drought conditions and xylem 
vulnerability to cavitation coordinated? An integrated analysis of photosynthetic, hydraulic and leaf level processes in two Mediterranean drought-resistant species. Environ Exp Bot 69:233-242

Wainhouse D (2004) Hylobius abietis - host utilisation and resistance. In: Lieutier F, Day KR, Battisti A, Gregoire JC, Evans HF (eds) Bark and wood boring insects in living trees in Europe, a synthesis. Springer, Dordrecht, pp 365-379
Xiao X, Xu X, Yang F (2008) Adaptive responses to progressive drought stress in two Populus cathayana populations. Silva Fenn 42:705-719

Yani A, Pauly G, Faye M, Salin F, Gleizes M (1993) The effect of a long-term water stress on the metabolism and emission of terpenes of the foliage of Cupressus sempervirens. Plant Cell Environ 16: 975-981 